Original paper UDC1:316.774(045)

doi: $10.21464 / \mathrm{sp} 32110$

Received: April 16 ${ }^{\text {th }}, 2016$

\author{
Clint Burnham, ${ }^{1}$ Katarina Peović Vuković ${ }^{2}$ \\ ${ }^{1}$ Simon Fraser University, Department of English, 8888 University Drive, Burnaby, B.C., CA V5A 1S6 \\ ${ }^{2}$ University of Rijeka, Faculty of Humanities and Social Sciences, Sveučilišna avenija 4, HR-51000 Rijeka \\ ${ }^{1}$ clint_burnham@sfu.ca, ${ }^{2}$ kpvukovic@ffri.hr
}

\title{
New Media as Event
}

\begin{abstract}
The Event is a philosophical concept coming out of the Continental tradition (Heidegger, Deleuze, Badiou, Žižek), useful for designating historical situation in which a multiplicity suddenly acquires a critical mass. After tracing the concept's genealogy in the aforementioned thinkers, we argue that the term is useful for thinking about the variety of technologies and practices (desktop computers, tele-computation, smartphones, social media) that are now designated as "new media". This designation, furthermore, allows us to understand and distinguish between meaningful critiques (political gestures such as those of Aaron Swartz), and those less meaningful (bit-torrenting and other forms of Internet piracy).
\end{abstract}

\section{Keywords}

event, new media, copyright, frames, Internet

\section{Introduction}

What does the philosophical concept of the Event have to tell us about media studies, about film, about new media, or about digital and networked media? Does a concept that describes haughty philosophical notions such as Heidegger's Gestell, or world-historical events ${ }^{1}$ like the French Revolution, help us to understand electric typewriters, Internet packet protocols or the complicated forms of determinism that cloud our thinking about the same? Is the Internet an Event? Did the coming of a publicly - mass - accessible media form, one that facilitated not only communication but cognitive interactions, constitute a rupture with the past, a new era making possible artistic expression, new social relations, political organizing, or scientific discoveries hitherto difficult or impossible? Is nothing the same after social media, after ubiquitous computing, after The Internet of Things, after clouds and stacks, and stacktivism?

In this paper we seek to bring the philosophy of the Event to bear on media studies, referencing a wide range of material: film, the novel, electronic technology, networked subjectivities. Our aim here is both to describe the Internet as the Event of the late 20th/early 21st century, and to focus on the problems of simplistic dismissals of the Internet, as co-opted and therefore useless from the point of view of revolutionary politics. We shall entertain precisely these

In this paper we follow philosophical convention, capitalizing the "Event" when designating the concept, and using the lower-case "event" when describing a run-of-the-mill occurrence. 
questions in turn, first of all discussing how Slavoj Žižek has developed his theory of the Event, referencing his predecessors, Martin Heidegger and Alain Badiou (but also Gilles Deleuze), but especially going into some detail with Žižek's theory, developed in his book Event (2014), of the Event as framing (enframing, but also fantasy as frame), and what this has to tell us about the "two frames" of media: the real and the virtual. The origins of Žižek's theory in Heidegger's ideas of Gestell, and Badiou's theory of the French Revolution, allow us to think historically about the technological revolution that is constituted by digital computing. It is our argument in this paper that now is the proper moment to start referring to the concept of the Event with respect to new media, since the Lacanian maxim that "truth has the structure of fiction" can be read as a definition of new media as such (Lacan 2002). New media is seen as a realistic illusion, what the Lacanians call the semblant, which lacks any referent in the real world (Miller 1990). The digital sign, for example, is acknowledged as post-photographic since it is disembodied, and it no longer guarantees any indexical relation between the referent and the image. Signifiers lose any stable meaning and value whether they are visual or orthographic (Hansen 2004; Virilio 1994). Furthermore, and finally, Žižek's theories of the gap between the frames, and over-identification as critique, provide a framework for considering recent attempts to evade, negate, or overturn the Event that is digital hegemony.

\section{The Event: Heidegger, Badiou, Žižek}

The Event is one of the most contested - but also "on trend" - term in contemporary thought (Badiou 2000; Badiou 2005; Badiou 2007; Bartlett, Clemens 2010; Brown 2004; Deleuze 1990; Hallward 2004; Johnston 2009; Norris 2009; Osborne 2013; Žižek 1999; Žižek 2007; Žižek 2014a; Žižek 2014b). In modern philosophy, the term was initially defined by Martin Heidegger. Daniela Vallega-Neu remarks of Heidegger's term Ereignis:

“... scholars (...) translate Ereignis not only as 'event' but also with the neologism 'enowning', or as 'appropriation', or as the 'event of appropriation'.” (Heidegger 1999, Vallega-Neu 2010, Wheeler 2015)

Heidegger sees a series of appropriating events as Events that transform dimensions of human sense-making - the religious, political, philosophical dimensions that define the culturally conditioned epochs of human history (Wheeler 2015). An Event presents a twofold process: human being is appropriated by Being, and Being needs human beings to disclose itself (Heidegger 1999: 6). Event is essential swaying of Being itself (ibid.), but also it needs Being to put Event into a question (ibid.: 7). In his development of Ereignis, Heidegger treats the Event as something larger than a moment in history: Events are not merely cyclical episodes. An Event is the truth of existence (Heidegger 1962). The enowning Event is truth of Being (Heidegger 1999). However, it is mostly understood as history - Geschichte (Heidegger 1999: 8) - where it must be understood much wider, as "historical" - das Historische (ibid.) - a "question of all questions" (ibid.). And it is through this process that historical subjects become able to participate in historicity. Since the enowning Event is the truth of being, Heidegger insists on the definition of the Dasein as something that is enowned in enowning (Heidegger 1999). Heidegger points out a conflict between history as an academic discipline, and his understanding of an event: history is more than the simple recounting of episodes from the past. Rather, Heidegger implies "a departure from a historiographic and objective 
C. Burnham, K. Peović Vuković, New Media as Event

understanding of historical events", moving away from such simplifications of historiography (Vallega-Neu 2003: 4). And it is especially in his Contributions that Heidegger questions the possibility of redefining history through the notions of a series of events and articulations of Being. We will return to Heidegger momentarily, and to his concept of Gestell (perhaps, Vallega-Neu argues, a preliminary form of Ereignis), but we must allow that concept to emerge at its proper place, in Žižek's discussion of the Event in his book of the same name (Žižek 2014b).

In Event Žižek offers a polysemic heterogeneity of the term (we will deal with the intervening philosopher Badiou below). What does it mean to treat something as an Event? Žižek offers:

"Event is not something that occurs within the world, but is a change of the very frame through which we perceive the world and engage in it." (Žižek 2014b) ${ }^{2}$

Such evental framing, Žižek argues, can sometimes be directly present as a fiction which nonetheless enables us to tell the truth in an indirect way. Here Žižek is following French philosopher Alain Badiou who, at some extent, elaborates against Heidegger's notion of history, and defines an Event on the basis of specific historical events, such as the French Revolution, while stressing, as does Žižek, the fictional, narrative nature of an event. Nevertheless, the fictional character of an Event is not its limitation but on the contrary - its necessity. In Being and the Event, Badiou proposes a tautology that establishes precisely this imperative. To verify whether an Event is presented in a situation, Badiou says that it is first necessary to verify whether it is presented as an element of itself, of itself qua set (Badiou 2005: 15). Badiou argues that to ask whether the French Revolution is really an Event in French history, we must first establish that it is definitely a term immanent to itself. Thus, he elaborates that the event 'The French Revolution' forms a one out of everything which makes up its site; that is, France between 1789 and, let's say, 1794 (Badiou 2005: 180). That site is filled with heterogeneous happenings. If historians try to describe the Event accurately or thoroughly as it was at the time of its happening, they can end up with a "forever infinite numbering of the gestures, things and words that co-existed with it" (Badiou 2005: 180). However, the French Revolution is an Event because it "both presents the infinite multiple of the sequence of facts situated between 1789 and 1794 , and, moreover, it presents itself as an immanent résumé and one-mark of its own multiple" (Badiou 2005: 180). The site coheres or coalesces around itself as Event. Moreover, an Event is always presented in a situation as the arrival in being of non-being, the arrival amidst the visible of the invisible. For the Event - and Žižek goes into some detail in this regard in The Ticklish Subject - raises the problem of the subject, of being infidelity to the Event (Žižek 1999). In other words, to treat an Event as an element of itself it has to be live (discursively) not because of its historical truthfulness, its greatness from a point of view of history. Such understanding, as we know, is usually unclear in the exact moment of the Event, which demands that history be rewritten or begun anew. It is almost the opposite - to treat an Event as an element of itself means that an Event is an Event because it is disputed in its elements but still not in its whole, as if an Event itself knows that it is an Event. This is the sense in which Deleuze talks about the Event, as a plague or war or wound that re- 
organizes itself, during the "present moment of its actualization" (Deleuze 1990). And this is just to stress that Badiou's event is germane to new media, which presents the multiple, from the development of the desktop computer in the late 1970s to the Internet coalescing in the 1990s, social media in the first decade of this century, and smartphones shortly after.

Now we can address Badiouian notion of an event, and return to Heideggerian notion of the Event. For the specificity of the Event is an existence, and at the same time the non-existence of an Event in the moment of its happening (which is the Badiouian lesson). The specificity of new media lies precisely in that tautology. It is not at all obvious whether and to which extent literacy and knowledge in the media age have changed. However, one could say that the new media as an Event is a one-multiple made up of all the multiples which belong to its site (all possible technical tools, from hardware to software, from users' affect to workers' virtual exploitation), and, on the other hand, the Event itself which is an almost eschatological fiction of itself, the harbinger of a new era. This dramatic entrance of new media is not only technical (the digitally produced sign, popular media frenzies), but also dramatic in its fictional nature - as with Virtual Reality (VR). It is not clear what virtual reality exactly means, but at the same time it is clear that VR dramatically changes our notion of space and time. VR is much more than its technical definitions. That is, in a pure technical sense, VR refers to such technologies as the Cave and HMD, or head-mounted displays, technological innovations that are still in the "goofy", prototype stage. However, VR is rarely used in that "strong" sense, but rather in the "weak" sense - virtual reality understood merely as a realistic illusion (Lévy 2001). And this is exactly the reason why Virilio describes the fictional and immersive character of digital media that engages subjects as the "narco-economy of computer communication" (Virilio 1995). But if we apply Badiou's Event to new media, we are reminded that such media exist precisely despite (and not because) of all the multiples which belong to its site. Whereas Lévy offers a techno-utopian take on new media, and Virilio a pessimistic antagonism, the evental nature of the Event is not due to its particular occurrences, but (and we are following Badiou here) a reflection of the retroactive intervention of our own filters.

The interpretive chasm that separates Lévy and Virilio is in turn reflected in the empirical multiples enumerated by Badiou when he lists some of the features of the (evental) site of the French Revolution:

“... the great electors of the General Estates, the peasants of the Great Fear, the sans-culottes of the towns, the members of the Convention, the Jacobin clubs, the soldiers of the draft, but also, the price of subsistences, the guillotine, the effects of the tribunal, the massacres, the English spies, the Vendans, the assignats (banknotes), the theatre, the Marseillaises, etc." (Badiou 2005: 180)

And can we not compare this list to today's site of new media that includes the digital devices, the smart phones and tablets, and laptops, and Google glasses, and Oculus Rift, but also their touchscreens and Bluetooth connections, and styluses and cases, and power cords and batteries, the Wi-Fi routers and the Internet cables and server farms, and the programs and apps, and storages and interfaces, and the workers at Foxconn, or workers digging for metals in the Congo and serving us at Apple stores, help-lines, or as feed scrubbers, and "like farmers" (Chen 2014, Emerson 2014). Our aim, of course, is not to undermine the historical gravity of the French Revolution by comparing it to simple (or not-so-simple) tools and devices. However, the moment when banality enters and takes over contemporary understandings of our tools, our 
historicizing of this highly technological present, an ontological comprehension of the Event is all the more crucial. We have to, then, reverse the dominant simplification and banality of narcissistic, individualistic approaches to technology and instead insist on the evental status of the informational/new media/post-industrial society.

This is to argue that to treat new media as an Event does not mean to define or categorize new media in a homogenizing fashion, especially since the new media paradigm shift can be approached to as either a change in material media or as a more profound redefinition of the production and reproduction of social life. But we must indeed make a strong and verifiable claim as to whether new media is an Event. In a way, by taking up the discussion of Badiou and tautology from above, new media has to recognize itself as the Event. This means without any a priori interventions, without the help of any positive or negative interpretations, either techno-futurist or techno-eschatologist notions. Here the true question is not the question about the impact of media (the banal questions one entertains from reporters: does new media change our historical horizons, our way of thinking, reading, writing, etc.), but instead a question of how or whether new media does all of these things despite any specific interpretation of that doing. That is, to speak of the Event of new media is to assert the unconscious of new media.

Being based on specific events and at the same time impossible to provide any proof for the Event, Badiouian event is defined against Heideggerian concept. Although serious predicates can be identified, those are all only effects of the way in which an event functions. New media precisely shows how Heideggerian event (banished from the common epistemological discussions on technology) can be fruitful for the exegesis. New media event functions both as Badiouian event as an element of itself, related to a specific moment in history, and as Ereignis - appropriated event, larger than a moment in history, an Event as truth of existence. What Heidegger's work does, and other existing concepts do not, is that Heidegger insists on the larger framing (enframing), historicity and not history, technological (technical) and not technology (technique). It is the reason why Žižek employs the notion of the Gestell to describes the ways in which new media is framed.

\section{The Event and the frame}

Žižek's Event was published as part of Penguin books series "philosophy in transit", which feature Wolfgang Tillman's photographs of London Tube commuters on the cover. And Žižek plays along gamely in the structure of his book (with various chapters as subway or train stations), with even an opening cultural example taken from another kind of train, Agatha Christie's 1957 novel 4:50 from Paddington. Žižek writes:

"Elspeth McGillicuddy, on the way to visit her old friend Jane Marple, sees a woman being strangled in the compartment of a passing train (...). It all happens very fast and her vision is blurred, so the police don't take Elspeth's report seriously as there is no evidence of wrongdoing; only Miss Marple believes her story and starts to investigate. This is an event at its purest and most minimal: something shocking, out of joint, that appears to happen all of a sudden and interrupts the usual flow of things; something that emerges seemingly out of nowhere, without discernible causes, an appearance without solid being as its foundation.” (Žižek 2014a)

Now, the incident Žižek is referring to bears its own examination, for purposes that will soon become clear. This is Christie's text: 
"[McGillicuddy's] train gathered speed again. At that moment, another train, also on a downline, swerved towards them, for a moment with almost alarming effect. For a time, the two trains ran parallel, now one gaining a little, now the other. Mrs. McGillicuddy looked down from her window through the windows of the parallel carriages. Most of the blinds were down, but occasionally the occupants of the carriages were visible. The other train was not very full and there were many empty carriages. At the moment when the two trains gave the illusion of being stationary, a blind in one of the carriages flew up with a snap. Mrs. McGillicuddy looked into the lighted first-class carriage which was only a few feet away. Then she drew her breath in with a gasp and half-rose to her feet. Standing with his back to the window and to her was a man. His hands were around the throat of a woman who faced him, and he was slowly, remorselessly, strangling her." (Christie 2011)

Mrs. McGillicuddy looked down from her window through the windows of the parallel carriages. This is an example, then, not only of an Event in all its raw, unanticipated rupture in the everyday (already prepared for us, and for Mrs. McGillicuddy, by the illusion of stasis between the two trains), but of that Event arriving with a frame, indeed with the doubled framing of the two train windows.

Consider, too, a scene in The Karate Kid where the young hero (Daniel, played by Ralph Macchio) is having a meal with his mother in a restaurant. Behind them is the restaurant window, and out that window (in a kind of reversal of Edward Hopper's famous painting Nighthawks from 1942) we see the hero's enemies leaving a karate studio across the street. Here we have framed, within the cinematic shot, the family unit (mother and son), and then framed, by the window behind them, what threatens that unit. This cinematic framing (through an arguably Wellesian "deep focus") is again a kind of doubling. And, these frames then are the frame that, as Žižek argues in Event, "regulate our access to reality" (Žižek 2014a: 30). That is, framing itself constitutes an Event. What does this mean? And what do these essential visual and literarycinematic frames have to do with the Internet?

In his discussion of the Event as "framing, reframing, enframing", Žižek argues that philosophy deals with "the transcendental horizon, or frame, of our experience of reality" (2014a: 10). Žižek expands on Badiou's notion of the fictitious character of the Event, and defines an Event as the frame through which we see the world (and which guides us in our actions in the world) - or the Event is a change in that frame, an enframing, a reframing, even a dissolution of a frame. As with Badiou's multiple and the one, and how that "truth with the structure of a fiction" applies to networked media, we can see that the frame then can be a way of thinking about new media. This is so because frames also have a psychoanalytic name: fantasy. We need fantasies - or frames - to sustain our relationships, for example, because, as Lacan famously said, "there is no sexual relationship" in the sense that there is no dominant narrative or frame to which one can reliably turn to help one's marriage or coupledom cohere (Lacan 1999). Of course, Žižek and Lacan have much to say about the role of fantasy, most notably, fantasy "teaches us how to desire" (Žižek 2014a). And it is in this context that Žižek turns to Heidegger:

“Gestell, Heidegger's word for the essence of technology, is usually translated into English as 'Enframing'. At its most radical, technology does not designate a complex network of machines and activities, but the attitude towards reality which we assume when we are engaged in such activities: technology is the way reality discloses itself to us in contemporary times. The paradox of technology as the concluding moment of Western metaphysics is that it is a mode of enframing which poses a danger to enframing itself: the human being reduced to an object of technological manipulation is no longer properly human; it loses the very feature of being ecstatically open to reality. However, this danger also contains the moment for salvation: the moment we become aware and fully assume the fact that technology itself is, in its essence, a 
mode of enframing, we overcome it - this is Heidegger's version of traversing the fantasy." (Žižek 2014a: 94)

Thus, in Žižek's reading of Heidegger, technology is a kind of Heideggerian enframing, a Gestell that also stands for a "fundamental fantasy" that structures our reality, that teaches us what to desire. Žižek's notion of history is a Heideggerian notion of history, "belonging to the essence of technology" (Heidegger 2013) that relates technology to the Event.

But if this is a correct reading, then what is the relationship between the terms or concepts of frame, Event, fantasy, and desire? What is notable about the Event - what is, in Badiou's translators' awkward neologism, "evental" - is not simply its happening, but what the Event does to our perception of the world, of how the world is framed. "Everything is different", "this changes everything" - such phrases indicate, in a fumbling way, not that the world qua world (the noumenal, in Kantian parlance) has changed, but that the phenomenon of the world has changed. Žižek rewrites Heidegger in a way that allows us to apply his understanding of an Event to contemporary technology. Why is this so? He insists on a certain fictional, unconscious status of the evental. In Heidegger's unconcealedness of the truth (aletheia), there is a difference between ontical and ontological (similar to Kant's noumenon and phenomenon). But Žižek inserts the Lacanian interpretation of the "ontological difference" as a "rift in the ontic order", which is parallel to the Badiouian admission that the Event is ultimately nothing more than a "symptomal torsion" in the order of Being, a matter of inconsistency, the return of the repressed, or even the objet petit a (Bartlett 2010; Johnston 2009; Žižek 1999). Why this twist of the constitutive nature of the (Hegelian) negation? The things that we cannot be aware of constitute a possibility of the truth (which is why we cannot be sure of something that we know). As Badiou has argued in his Theory of the Subject, this constitutes an appropriation of the classic Lacanian subversion of the subject (Badiou 2009).

What is crucial to our argument is how this "double" enframing functions in a similar way with respect to digital devices, interfaces, and social media. That is, there is always a framing that is simultaneously the thing or the object (the stuff that is the phone or tablet or laptop, etc.) and the virtual (images, code, the visual). Take the example of a rather ordinary, old-ish, iPhone 4, which one of this paper's authors has owned for a few years now. When I want to, say, go onto social media network called Facebook, firstly I must push the small button at the bottom of the phone. Then I swipe the unlock slide, enter in my phone's passcode, and am confronted with a few screens worth of apps (icons for apps). I press on the Facebook's " $\mathrm{f}$ " logo, then the status button (which is itself an icon of a pen on a slant in a box, as if writing paper). Or, if I just want to read my friends' status updates, I start scrolling through, phone in my left hand, thumb moving from bottom to top of the screen. The phone itself constitutes the first frame. It is a physical frame - the Internet is a thing, an object (Blum 2012). What is "in" or "on" the screen - icons, boxes, images - then is the second frame. This second frame may be multiple (frames within frames) but their virtuality/visuality makes them a One, one frame, in counter-distinction to the other One frame, that of the device.

What is revolutionary in such framing, one may ask? Is it not, first of all, a betrayal of the initial Event of media, a withdrawal of the original idea of universal connectivity, and its subversion via tactical media? We could be - and this is a difficult admission to make - viewing this new media as Event in the same disastrous way in which Heidegger did when he sought out Nazism 
as an Event (Marty 2015, Žižek 2008). The very philosopher who focused his interest on the enigma of ontological difference fell into the same trap of conferring upon Nazism an ontological dignity (Žižek 1999; Žižek 2014). What if the Event is a failed Event, a betrayal of the Event (Not in Badiouian understanding of betrayed truth process)? If there is something evental in new media technology that has to do with the future as "having-been/gesewene", as future that is located in the past? The actual evental status of new media lies in its repetition/retrieval of its past, not "of the past as it was", but of "that in the past which the past itself, in its reality, betrayed, stifled, failed to realize" (Žižek 2008: 141). To paraphrase Žižek, to treat the new media as an Event means to bring out the non-realized potentials of its past: data retrieval as Freudian "compulsion to repeat". Are we in danger, as is Žižek, of detecting in Nazism moments that need to be realized? This, of course, is also Fredric Jameson's argument with respect to the Utopian dimension of all ideologies (Jameson 1971). Or: what new media constitutes as an Event is precisely such a Utopian moment that is lacking in Nazism, a Utopian opening present to those moments described by Badiou and Žižek: since the "difference is strictly immanent to enthusiastic unity" (Žižek 2008: 116). Which is to say, that if new media is an Event, this is so because its common denominator is the Rancièreian "part of no-part" that functions as a "universal singularity" embodying the universal dimension: not so much a commercialized version of Internet or digital connectivity (which would be the failed Event, the disaster), which we avoid via the very embracing of that failure (try again, fail again): to arrive at the ontological truth of the Event, one has to err ontically (Žižek 1999, Žižek 2007).

\section{Hiding Heidegger between the frames}

The digital, the Internet, is an evental frame in the spatial manner that changes our relation to the world. And so we sit on trains or park benches hunched over our devices. Does this isolate us, remove us from our surrounds? Surely - although whether it does so any more than if we are reading a newspaper or a novel, we are not certain (even this scene that we use to describe framing is itself framed). What may help us here is to continue to read Žižek on the question of frames, and doubled frames in particular. In his book on the Polish filmmaker Krzysztof Kieślowski, a slim volume called The Fright of Real Tears, Žižek describes an impromptu theory of the "two frames" that he came up with at "an art round table":

"The frame of the painting in front of us is not its true frame; there is another, invisible frame, implied by the structure of the painting, which frames our perception of the painting, and these two frames do not overlap - there is an invisible gap separating the two." (Žižek 2001: 5-6)

Then Žižek, after discussing this concept further, declares that he was dismayed that his "total bluff" of an idea was then taken up by the other participants in the round table (whom he is polite enough not to mention), but of course this incident is nothing more than the embarrassment we all feel, as intellectuals, when we are riff on an idea and then witness its success. Indeed, Žižek, toward the end of The Fright of Real Tears, returns to this idea, adding that "[t]he pivotal content of the painting is not rendered in its visible part, but is located in this dislocation of the two frames, in the gap that separates them" (Žižek 2001: 5-6), connecting painting with film (he mentions Edward Hopper's art, "where it seems as if the picture's frame has to be redoubled with a window-frame"). 
Matthew Filsfeder, in his book on The Symbolic, the Sublime, and Slavoj Žižek's Theory of Film, remarks that we should take Žižek's second iteration of the theory seriously, arguing that Žižek merely maintains a "cynic's distance" from the first as a form of "ideological belief" (Flisfeder 2013). And as if to continue the (Maoist?) self-critique, Žižek makes a similar argument in Less than Nothing:

"My procedure here perfectly illustrated the point I was (and am) repeatedly trying to make apropos of today's predominant attitude of cynicism and not-taking-oneself-seriously. Even when a subject mocks a certain belief, this in no way undermines the belief's symbolic efficacy - the belief often continues to determine the subject's activity." (Žižek 2012: 87)

Flisfeder makes another point with respect to Žižek's two frames, arguing that

“... the two frames, the visible and the invisible, represent the relation between the Symbolic and the Imaginary in Lacanian psychoanalysis - that is, between the apparent content and the obscene supplemental underside, and the gap between them is the Real, or the place of the subject." (Flisfeder 2013: 102)

These discussions of frames and doubled frames digital can help us in our question of the Event of the Internet - or even to ask: is new media an Event? To think of the Internet or new media as an Event means, first of all, to argue that our digital interfaces frame our understanding of the world. Which seems fairly uncontroversial as a thesis. And, then, it is to argue that, as Žižek puts it in The Parallax View where, three years after The Fright of Real Tears, he expands on the notion of the frames, the "frame is always-already redoubled: the frame within 'reality' is always linked to another frame enframing 'reality' itself" (Žižek 2004: 29). This "gap between reality and appearance", Žižek argues, means that reality appears to be itself, with a minimal gap, a "minimal difference" (Žižek 2004: 29). This "always-already redoubling" is demonstrated perfectly in Gertrude Stein's modernist classic The Autobiography of Alice B. Toklas. Alfy Maurer, "an old habitué of the house", defends Cézanne's paintings:

"Of course you can tell it is a finished picture, he used to explain to other American painters who came and looked dubiously, you can tell because it has a frame, now whoever heard of anybody framing a canvas if the picture isn't finished?" (Stein 2014: 10)

Here Stein - or her narrator Toklas - or the collector Maurer - implicitly connects the physical frame of the painting with the institutional framing of art itself (a contested struggle within the book, with its situating of Stein's salon versus the great modernist upheavals then ongoing in Paris).

Let's return to our iPhone example. There is the visual frame that is the way in which the interface (of the operating system, with its passcodes, icons and comment fields) is structured. And then there is the physical, or haptic, or thing-ness, frame of the digital device itself, the "handheld device", which we touch and carry around and occasionally plug in to recharge, or to connect "to the Internet". And these constitute, qua redoubled frame, an Event, a frame or fantasy of our perception, of our desire, of how we see and act upon the world. But - then - it is the gap between these frames, between the virtual frame and the physical frame, where the Event actually occurs. For this is where, as Flisfeder so perspicuously puts it, we emerge as subjects. And, as we will find out later in our reading of Žižek's Event:

“... the true Event is the Event of subjectivity itself (...) the status of subjectivity itself is eventual." (Žižek 2014a: 67) 
In a similar fashion, Scott McCloud has argued that comics are an "invisible art", that the interpretive actions of readers take place "in the gutter" or between the panels (frames) of the graphic narrative (McCloud 1993). Johanna Drucker has most productively connected that specific site of the frame to the digital interface. Arguing that "we have moved from a traditional discussion of graphical formats as elements of mise en page to a sense that we are involved with a mise en scene or système" (Drucker 2011: 7). She nonetheless steers clear of what Alex Galloway identifies, in his discussion of The Interface Effect, as the sense of "windows, screens, keyboards, kiosks, channels, sockets, and holes" as threshholds (Galloway 2012).

Here again we see the same doubled frames - the frame of the virtual, the interface as software and images and icons (McCloud, Drucker), and the frame as, in the second half of Galloway's list, the holes and plugs and objects that enable or hold those virtual frames. Thus Drucker is surely correct to critique how interface studies has been "substituting the idea of a 'user' for that of a 'subject"" (Drucker 2011: 1), echoing Jodi Dean's assertion that "the matter of the Internet has less to do with bits, screens, code, protocol, and fiber-optic cable than it does with people" (Dean 2014). These lists, however, in Galloway and Dean (windows, screens, keyboards, kiosks, channels, sockets, holes, bits, screens, code, protocol) are symptomatic of what is in Object-Oriented Ontology called the "Latour Litany", or the list of objects which intends to demonstrate some hitherto unanticipated partition or barrier that is, presumably, independent of subjectivity (Bogost 2012). For example, later in The Interface Effect, Galloway argues that, as the society of control replaces the society of spectacle, and the lens replaces the mirror (or, in his more ornate vocabulary, the dioptric replaces the catoptric), the very invisibility and transparent operability of the interface is its own worst enemy: "frames, windows, doors, and other thresholds are those transparent devices that achieve more the less they do" (Galloway 2012: 25). This sounds not a little Orwellian, both in terms of its ominousness and in the call, in George Orwell's classic essay "The Politics of the English Language" for prose as clear as a windowpane (even if Galloway is being descriptive rather than prescriptive). Which is not to say that Galloway is not correct, but perhaps that it is worth looking at those fails of the systems, those gaps between the frames, rather than focusing on the big Other of an over-arching system of control.

Žižek accepts the frame's "inconsistency", its "meaningless and impenetrable presence" of "over-identification" with the frame. These concepts can be compared with, on the one hand, the variety of ways in which we are told to deal with social media today (from cleanses and fasts to non-commercial alternative), and, in a more technological way, to the variety of responses discussed by Galloway in his book Protocol: How Control Exists after Decentralization. Galloway contrasts two kinds of resistance: on the one hand, the total withdrawal exemplified in the "Unabomber" (Theodore Kaczynski), and on the other hand, attempts to "refuse protocol (...) to direct these protocological technologies (...) toward what Hans Magnus Enzensberger calls an 'emancipated media' created by active social actors rather than passive users" (Galloway 2001: 16).

And so Žižek also, in Event, in his discussion of framing, enframing, reframing, connects the frame as Event to the frame as fantasy. Does this mean that fantasy is an Event? And what does Žižek mean by saying that we need to overcome this enframing, we need to "traverse the fantasy" of technology? These are two sets of questions - what is fantasy, and what does it mean to traverse it? First of all, then, in the Lacanian-Žižekian tradition, fantasy is 
not merely an illusion, or a daydream, rather, it is more fundamental to our everyday life. Fantasy both structures our reality, our identity (I am a woman or a man of a certain age and profession, I have certain hobbies or books that I have read or political activities that I have undertaken, I live in a certain country and have an intimate partner, a child, and so on) and it structures our desire. And these things are connected: as a university professor, I have certain desires (how I teach and do research, for promotion or for effect in my community). And the fantasy that structures my desire, that teaches me what or how to desire, then is centered on an objet petit $a$ : the object of my desire, this "little bit of the Real", that which is "in you more than you". The Lacanian formula or matheme for desire is $\$<>a$. That is, I am constituted as a subject (as a barred subject, a divided or split subject, hence \$) in relation to (the lozenge or $<>$ denoting moving to and away from, or even circling around...) the objet petit $a$.

Žižek connects the question of the "frame" and the objet petit $a$ in a slightly earlier discussion of the Hollywood "production of the couple" (Žižek 2012). One feature of the objet petit $a$, he says there, is that it designates what is taken from, or subtracted, from reality (he is riffing off of Badiou here as well) - and reality gains its consistence precisely from this subtraction, this loss. That is, here Žižek's perspicuous program is quite clear: we do not traverse the fantasy, we do not overcome the enframing by "transcending" it, by going on a Facebook cleanse or requiring, like the proverbial millionaire at his wedding, that everyone leave their smartphones outside:

“... while it may seem obvious that psychoanalysis should liberate us from the hold of idiosyncratic fantasies and enable us to confront reality the way it is, this is precisely what Lacan does not have in mind: traversing the fantasy does not mean simply going outside the fantasy, but shattering its foundations, accepting its inconsistency." (Žižek 2014a)

\section{Rather:}

"The way to break out of the Hollywood frame is thus not to treat the Thing as just a metaphor of family tension, but to accept it in its meaningless and impenetrable presence.” (Žižek 2014a)

And, finally:

"The ideologico-political dimension of this notion of 'traversing the fantasy' was made clear by the unique role the rock group Top lista nadrealista (The Top List of the Surrealists) played during the Bosnian war (...) they daringly mobilized all the clichés about 'stupid Bosnians'." (Žižek 2012)

Rejecting or claiming to have eluded the frame in which social media or digital devices operate (which is to say the double frame, the virtual and the material frames) - would only be delusional, for two reasons. First, as argued above, such a move only results in another frame (hence the commonplace fetishes today of the artisanal, the handmade or DIY, the organic or local), another $o b$ jet petit $a$ - and the structure of fantasy would remain intact. Secondly - and this is a broader claim of Žižek's - the frame requires precisely this fantasy of not believing. Again this argument breaks down into two: first, the longstanding claim of Žižek that ideology requires a minimal distance or cynical disavowal (as in Flisfeder's argument with respect to Žižek and the two frames in Fright of Real Tears). That is, our very "passionate (dis)attachment" allows us to enjoy our devices and apps even as we misrecognize the very conditions for that enjoyment.

Third and finally, that very "minimal distance", or the difference between the two frames, is where our gap or lack as subjects is founded. Think of when you purchase a new phone or tablet or computer. For a time, it is exciting - a 
new fetish object to slip into your pocket or casually open on a café table, hook up to a projector in the lecture hall, etc. But once all of your apps and programs and music and files have been restored from the cloud - isn't it now boring? Old wine in new bottles, etc. Or, you find a great new app - one that allows you to find a rental car, or get a hot new date, or listen to the $\mathrm{BBC}$ anywhere. Again, excitement, fetishization for a while, and then - well, still got "the crap phone", don't you? The chipped edge or that crack your thumb keeps getting caught on (surely the cracked iPhone is the ultimate "fragile absolute"), the duct tape peeling off where you stuck it over the Apple logo on your laptop - they haven't changed.

Thus, what to do? Instead of this acting out, one can traverse the fantasy of the digital by accepting its "inconsistency", its "meaningless and impenetrable presence", which is to say, as Žižek has argued for twenty years, to engage in the "over-identification" with ideology (with fantasy, with the frame), as he calls for in The Plague of Fantasies, referring to Jaroslav Hašek's The Good Soldier Schweik, "whose hero wreaks total havoc by simply executing the orders of his superiors in an overzealous and all-too-literal way" (Žižek 1997: 29). Simply put, this is because we only think we are rejecting a given frame or fantasy (or, to use a more Marxist term, ideology). And yet, that frame still does its work on us. Of course this does not mean that we must put up with irrational laws. Quite the contrary. As Mladen Dolar argues, the admission in advance of a law's unfoundedness entails a kind of degradation of the law (Dolar 1991). It deprives the law of its internal authority and clears a place for "real" authority to be established: the authority of reason and truth. In the degradation of the inner reasoning and authority of technology we could free ourselves from the slavery of user-consumer logic. In order to start freeing ourselves of unquestionable laws and rules, of visions of technology as a commodity and consensus of the global profit orientation of capitalist networks, one must abandon the logic of natural technological progress. In order to engage in a critique of political economy, one must abandon the religious fetishistic belief in techno-progress.

\section{Conclusion: the right way, the wrong way (in reverse)}

In Žižek's work we find the exhortation to traverse the fantasy, to constitute a fidelity to the Event, by way not of a minimal distance from the fantasy (which is the founding principle of transgression), but through over-identification (Žižek 1997, Žižek 2014a). Two examples from digital culture and new media should make this precept clear. Copyright infringement, from the early $21^{\text {st }}$ century examples of filesharing and P2P platforms (from Gnutella to Napster) to contemporary bit-torrenting and Pirate Bay constitute the extension of the pleasure principle (now a hegemonic ideology of late capitalism). Through a minimal distance from the master Signifier of capital, the downloader is able to ensure herself that they are striking a blow for freedom, whereas, similar to home tapers in the $1980 \mathrm{~s}$, one is merely substituting one technological consumption (the purchase of bandwidth, hardware, and Wi-Fi signals) for another (films, CD's, MP3's) (Sterne 2012). A strikingly different example of such negation can be seen in the work of such activists as Julian Assange, Edward Snowden, and Aaron Swartz. In all of these cases, arguably an over-identification with the "information wants to be free" precept of digital hegemony results in very different conditions than the illegal downloaders; they stand as examples of the "obscene underside" of technology (and new media) today. Assange, Snowden, and Swartz show very clearly that traversing the fantasy of new media does not entail a simple abandonment of technology. On the con- 
trary, accepting the official story of distribution and open source code, means accepting the inconsistencies, the symptomal torsions, that constitute digital hegemony today. Insisting upon, indeed following to their ends, the inconsistencies of new media qua Event. And it is in following Badiou and Žižek, in arguing that a concept of the Event contains infinite - multiple - gestures that are immanent to itself. Such a theory of the Event thus inquires thoroughly into the notion of the frame as Event, enframing or even a doubled frame, a series of frames that are both epistemological (they frame the world, like Kantian faculties) and ontological (the world does not exist without its frames). Furthermore, as pointed out with respect to new media, to is multiples of objects and interfaces, of the thing and the virtual, these frames are both constitutive of the Real and are a way in which the digital constitutes an Event.

\section{Literature}

Badiou, A. (2009): Theory of the Subject, translated by Bruno Bosteels. London: Continuum.

Badiou, A. (2007): “The Event in Deleuze”, Parrhesia 2 (2007), pp. 37-44.

Badiou, A. (2005): Being and Event, translated by Oliver Feltham. London: Continuum.

Badiou, A. (2000): Deleuze: The Clamour of Being, translated by Louise Burchill. Minneapolis: University of Minnesota Press.

Bartlett, A. J.; Clement, J. (eds. 2010): Alain Badiou: Key Concepts. Durham: Acumen.

Blum, A. (2012): Tubes: A Journey to the Center of the Internet. Toronto: HarperCollins.

Bogost, I. (2012): Alien Phenomenology, or What It's Like to Be a Thing. Minneapolis: University of Minnesota Press.

Brown, N. (2004): “Alain Badiou and Slavoj Žižek: Waiting for something to happen”, The New Centennial Review 4 (3/2004), pp. 289-319. doi: https://doi.org/10.1353/ ncr.2005.0014.

Chen, A. (2014): “The Laborers Who Keep Dick Pics and Beheadings Out of Your Facebook" (October 23, 2014), Wired. Available at: https://www.wired.com/2014/10/contentmoderation/ (accessed on: April 15, 2016).

Christie, A. (2011): The 4:50 from Paddington. New York: William Morrow.

Dean, J. (2014): The Real Internet. Žižek and Media Studies. London: Palgrave Macmillan.

Deleuze, G. (1990): The Logic of Sense, translated by Mark Lester. New York: Columbia University Press.

Drucker, J. (2011): "Humanities Approaches to Interface Theory", Culture Machine 12 (2011), pp. 1-20. Available at: https://www.culturemachine.net/index.php/cm/article/viewArticle/434 (accessed on April 15, 2016).

Emerson, L. (2014): Reading Writing Interfaces: From the Digital to the Bookbound. Minneapolis: University of Minnesota Press, 2014.

Filsfeder, M. (2013): The Symbolic, the Sublime, and Slavoj Žižek's Theory of Film. London: Palgrave Macmillan, 2013.

Galloway, A. R. (2012): The Interface Effect. London: Polity Press.

Galloway, A. R. (2001): Protocol: How Control Exists after Decentralization. Cambridge: MIT Press, 2001.

Hallward, P. (2004): Think Again: Alain Badiou and the Future of Philosophy. London: Continuum, 2004.

Hansen, M. B. N. (2004): New Philosophy for New Media. Cambridge: MIT Press.

Heidegger, M. (2013): The Event, translated by Richard Rojcewicz. Bloomington: Indiana University Press. 
Heidegger, M. (1999): Contributions to Philosophy (From Enowning), translated by Parvis Emad; Kenneth Maly. Bloomington: Indiana University Press, 1999.

Heidegger, M. (1962): Being and Time, translated by John Macquarrie; Edward Robinson. Oxford: Blackwell University Press.

Jameson, F. (1971): Marxism and Form: Twentieth Century Dialectical Theories of Literature. Princeton: Princeton University Press.

Johnston, A. (2009): Badiou, Žižek, and Political Transformation: The Cadence of Change. Evanston: Northwestern University Press.

Lacan, J. (2002): Écrits, translated by Bruce Fink. New York: W. W. Norton \& Company.

Lacan, J. (1999): Seminar XX: On Feminine Sexuality, translated by Bruce Fink. New York: W. W. Norton \& Company.

Lévy, P. (2001): Cyberculture, translated by Robert Bononno. Minneapolis: University of Minnesota Press.

Marty, É. (2015): Radical French Thought and the Return of the "Jewish Question", translated by Alan Astro. Bloomington: Indiana University Press.

McCloud, Scott (1993): Understanding Comics. New York: Kitchen Sink Press.

Miller, J-A. (1990): Microscopia: An introduction to the reading of Television. New York: W. W. Norton \& Company.

Norris, C. (2009): Badiou's Being and Event: A Reader's Guide. London: Continuum.

Osborne, P. (2013): “More than everything: Žižek’s Badioiuan Hegel”, Radical Philosophy 177 (2013), pp. 19-25.

Stein, Gertrude. The Autobiography of Alice B. Toklas, in: Selected Writings of Gertrude Stein. New York: Vintage Books, 2014.

Sterne, J. (2012): MP3: The Meaning of a Format. Sign, Storage, Transmission. Durham: Duke University Press.

Vallega-Neu, D. (2010): “Ereignis: The Event of Appropriation”. In: Davis, B. W. (ed.), Martin Heidegger: Key Concepts, pp. 140-154. Durham: Acumen.

Vallega-Neu, D. (2003): Heidegger's Contributions to Philosophy: An Introduction. Bloomington: Indiana University Press.

Virilio, P. (1994): The Vision Machine, translated by Julie Rose. Bloomington: Indiana University Press.

Wheeler, M. (2015): "Martin Heidegger", The Stanford Encyclopedia of Philosophy. Available at: http://plato.stanford.edu/archives/fall2015/entries/heidegger/ (accessed on April 15, 2016).

Žižek, S. (2014a): Absolute Recoil: Towards a New Foundation of Dialectical Materialism. London: Verso.

Žižek, S. (2014b): Event. London: Penguin.

Žižek, S. (2012): Less than Nothing: Hegel and the Shadow of Dialectical Materialism. London: Verso.

Žižek, S. (2008): In Defence of Lost Causes. London: Verso.

Žižek, S. (2007): "On Alain Badiou and Logiques des mondes”, Lacan dot com. Available at: http://www.lacan.com/zizbadman.htm (accessed on April 15, 2016).

Žižek, S. (2004): The Parallax View. Cambridge: MIT Press.

Žižek, S. (2001): The Fright of Real Tears: Krszystof Kieślowski Between Theory and Post-Theory. London: British Film Institute.

Žižek, S. (1999): The Ticklish Subject. London: Verso.

Žižek, S. (1997): The Plague of Fantasies. London: Verso. 


\title{
Clint Burnham, Katarina Peović Vuković
}

\section{Novi medij kao Događaj}

\begin{abstract}
Sažetak
Događaj je filozofski koncept koji proizlazi iz kontinentalne tradicije (Heidegger, Deleuze, Badiou, Žižek), koristan za označavanje povijesne situacije u kojoj multiplicitet zadobiva kritičnu masu. Nakon praćenja genealogije koncepta u navedenih autora, argumentiramo da je termin koristan za mišljenje raznih tehnika i praksi (računala, telekomputacija, pametni mobiteli, društveni mediji) koje se označava kao »novi medij«. Ova oznaka, nadalje, omogućuje nam razumjeti razliku između smislene kritike (političke geste poput one Aarona Swartza) i manje smislene kritike (bit-torrenting i drugi oblici piratstva na internetu).
\end{abstract}

\section{Ključne riječi}

događaj, novi medij, autorska prava, okviri, internet

\section{Clint Burnham, Katarina Peović Vuković}

\section{Neues Medium als Ereignis}

\begin{abstract}
Zusammenfassung
Das „Ereignis “ ist ein philosophisches Konzept, das aus der kontinentalen Tradition (Heidegger, Deleuze, Badiou, Zižek) hervorgeht und für die Kennzeichnung der historischen Situation nützlich ist, in welcher die Multiplizität eine kritische Masse erhält. Nachdem wir die Genealogie des Konzepts bei den vorgenannten Autoren verfolgt haben, argumentieren wir, dass sich dieser Terminus für das Nachdenken über unterschiedliche Techniken und Praxen (Computer, Telecomputation, Smartphones, soziale Medien), die man als „,neues Medium “ bezeichnet, als brauchbar erweist. Fernerhin ermöglicht uns diese Bezeichnung, die Differenzierung zwischen einer sinnvollen Kritik (politische Gesten wie jene Aaron Swartz') und einer weniger aussagekräftigen Kritik (BitTorrenting und andere Formen der Piraterie im Internet) zu begreifen.
\end{abstract}

\section{Schlüsselwörter}

Ereignis, neues Medium, Urheberrechte, Rahmen, Internet

\section{Clint Burnham, Katarina Peović Vuković Nouveau média en tant qu'Événement}

\begin{abstract}
Résumé
"L'Événement » est un concept philosophique qui découle de la tradition continentale (Heidegger, Deleuze, Badiou, Žižek) et qui est utile pour exprimer la situation historique dans laquelle la multiplicité prend la forme d'une masse critique. Après avoir observé la généalogie du concept chez les auteurs mentionnés, nous argumentons en vue de montrer que le terme est utile pour penser diverses techniques et pratiques (ordinateurs, télécomputation, smartphones, médias sociaux), que nous désignons de "nouveaux médias ». Cette qualification, par la suite, nous permet de comprendre la différence entre une critique sensée (le geste politique à l'instar de celui d'Aaron Swartz) et les critiques moins sensées (le bit-torrent ou d'autres formes de piratages sur internet).
\end{abstract}

\section{Mots-clés}

événement, nouveau média, droits d'auteur, cadres, internet 